International Journal of Civil Engineering and Technology (IJCIET)

Volume 9, Issue 10, October 2018, pp. 50-60, Article ID: IJCIET_09_10_006

Available online at http://www.iaeme.com/ijciet/issues.asp?JType=IJCIET\&VType=9\&IType $=10$

ISSN Print: 0976-6308 and ISSN Online: 0976-6316

CIAEME Publication

Scopus Indexed

\title{
DIMENSIONS OF CULTURAL INTELLIGENCE AND TECHNOLOGY SKILLS ON EMPLOYEE PERFORMANCE
}

\author{
Abdi Setiawan, Hasrul Azwar Hasibuan, A. P. U. Siahaan, Muhammad Isa Indrawan, \\ Rusiadi, Irma Fatmawati, Emy Wakhyuni, Desi Astuti, Ade Novalina, Sri Rahayu \\ Universitas Pembangunan Panca Budi, Medan, Indonesia
}

\begin{abstract}
Intelligence Dimension of Culture and Force This study examines the phenomenon of problems that occur, namely the lack of knowledge possessed by employees in solving problems, lack of strategies owned by employees so that it is difficult to achieve targets set by the company, low motivation of employees so that it affects employee productivity, the presence of bad behavior among employees that result in collaboration within the company does not run in accordance with what is expected by the company, and there are disputes between employees and outsiders due to the lack of interpersonal skills possessed by employees. The purpose of this study was to analyze four factors of cultural intelligence namely knowledge, strategy, motivation and behavior in developing interpersonal skills and employee performance, using a quantitative approach. The sample used in this study were 60 respondents, this study used path analysis. The research results that knowledge has a direct effect on performance and can also have an indirect effect. Strategy directly affects performance and can also have an indirect effect, from strategy to interpersonal skills to performance. Motivation has a direct effect on performance and can also have an indirect effect, from motivation to interpersonal skills to performance. Behavior directly affects performance and can also have an indirect effect, from behavior to interpersonal skills to performance.
\end{abstract}

Key words: cultural intelligence, interpersonal skills, employee performance

Cite this Article: Abdi Setiawan, Hasrul Azwar Hasibuan, A.P.U. Siahaan, Muhammad Isa Indrawan, Rusiadi, Irma Fatmawati, Emy Wakhyuni, Desi Astuti, Ade Novalina, Sri Rahayu, Dimensions of Cultural Intelligence and Technology Skills on Employee Performance. International Journal of Civil Engineering and Technology, 9(10), 2018, pp. 50-60.

http://www.iaeme.com/IJCIET/issues.asp?JType=IJCIET \&VType=9\&IType $=10$

\section{INTRODUCTION}

Employee performance as a result of work in quality and quantity that an employee achieves in carrying out tasks by the responsibilities assigned to him [1]-[3]. There is a need for factors that significantly influence the cultural intelligence and interpersonal skills of these 
employees to create the high performance for employees. Other factors that affect employee performance include talent, education and training, environment and facilities, work climate, motivation, knowledge, and ability of industrial relations, technology and management, opportunities for achievement, behavior, strategies and so on. There are several opinions regarding factors that affect employee performance [4]-[7] Spencer (2008) factors of knowledge, skills, and abilities are needed to support performance. Knowledge, skills, and abilities are fundamental competencies of a person to be able to demonstrate adequate performance. Skills are usually associated with things such as a person's values, standards and outlook on life [8]-[11] It is the basis of aspects of personality that are important for doing essential and responsible tasks. Not all personal aspects of an employee are abilities, only personal aspects that encourage him to achieve superior performance are abilities [12].

One personal aspect which is ability is interpersonal skills. Interpersonal skill is one's ability to create relationships, build relationships and maintain social relations so that both parties are in a favorable situation [13]. Interpersonal skills are built by the core ability to recognize interpersonal differences [14]. At this time we interact with people who have different cultural backgrounds with us, so we are required to be harder to understand, accept and adapt. One way to improve interpersonal skills is by recognizing and developing cultural intelligence.

Other factors besides interpersonal skills that can produce optimal performance are cultural intelligence [15]. Cultural intelligence refers to the ability of individuals to understand, think and behave effectively in situations characterized by intercultural differences. Earley shows research evidence that cultural intelligence can improve interpersonal skills and employee performance. Earley revealed that in cultural intelligence there are factors that significantly influence the success of individuals in achieving success. Factors that exist in cultural intelligence include knowledge, strategy, motivation, and behavior [16].

In order to achieve the quality of human resources that meet the requirements by the development and standards of modern companies, some programs should be carried out. One of the improvement programs is by providing innovative education and training both internally and externally. The training and education programs referred to are in the fields of religion, health and other fields. If the achievement of one person is considered good or increases significantly, then sometimes the employee does not have to be registered in a position transfer program if the employee concerned does not want to transfer or prefers to remain in the original position. Employees who excel in their field of work, can satisfy all parties and benefit the company. Generally, the employee will be considered by the company, especially the company concerned has a clear and transparent measuring instrument [17].

\section{THEORIES}

\subsection{Cultural Intelligence}

Earley and Ang first introduced the concept of cultural intelligence in 2008. Initially, the concept emerged and developed among global businesses. Globalization has increased intercultural interaction, thus increasing the likelihood of misunderstanding, cultural tension, and conflict. This cultural intelligence is similar to social intelligence and emotional intelligence. Social intelligence refers to the ability to understand and manage social relationships with others. Emotional intelligence is the ability to understand and deal with and manage one's own emotions and emotions [18]. Cultural intelligence is the ability to understand, manage and deal with the emotions of others in an intercultural context. The person who first revealed the existence of intelligence other than academics that can influence a person's success is Gardner. Other intelligence is called cultural intelligence or cultural intelligence. Cultural intelligence is the ability to adapt effectively to new cultural contexts. Cultural intelligence is the ability to function effectively in various cultural contexts [19]. 
Abdi Setiawan, Hasrul Azwar Hasibuan, A.P.U. Siahaan, Muhammad Isa Indrawan, Rusiadi, Irma Fatmawati, Emy Wakhyuni, Desi Astuti, Ade Novalina, Sri Rahayu

Cultural intelligence is an ability to provide a good response from the view of truth or fact to listen to the whispers of emotions make it as a source of information is important to understand yourself and others and achieve goals [20]. Cultural intelligence is the ability in the field of intercultural interaction, namely the ability to face frustration, the ability to control emotions, the spirit of optimism, and the ability to establish relationships with others or empathy. The differences between cultures have long been a challenge in the face of multinational organization organizations, ineffective use will be able to achieve goals in building productive relationships and achieving work success. The cultural intelligence has a positive influence on the development of one's interpersonal skills and performance. Cultural intelligence is associated with human resource management systems; for example for training, in this case, cultural intelligence can be used as a basis for providing training specifically. The resulting training can improve employee performance.

\subsection{Cultural Intelligence, Interpersonal Skills and Employee Performance}

The world of work has various problems and challenges that must be faced by employees, such as intense competition, task demands, an uncomfortable working atmosphere and problems with relationships with others. These problems in the world of work are not things that only require their intellectual abilities, but in solving these problems more cultural or cultural intelligence is needed. If someone can solve problems in the world of work that are related to culture, then he will produce better work. Earley and Ang, based on their research and experience in advancing the company argue that the existence of good cultural intelligence will make an employee display better performance and interpersonal skills. Earley and Ang in his book once said that to achieve success in the world of work is not only the intelligence needed but also cultural intelligence. Specifically, corporate leaders need high cultural intelligence because in an organizational environment, interacting with many people both within and within the work environment plays an essential role in shaping the morals and discipline of workers.

Employee performance lately is not only seen by intellectual factors but also determined by cultural factors. Someone who can use his culture correctly will be able to produce good performance too. Cultural intelligence is a factor that is as important as a combination of technical capabilities and analysis to produce optimal performance. One aspect of cultural intelligence is motivation [21]-[24]

A study conducted by Earley and Ang, on several research subjects in several companies, the results obtained show that employees who have high cultural intelligence values will produce the better performance that can be seen from the quality and quantity given the employee is against the company. Earley also revealed that even though a person has a pretty good performance but if he has a closed nature and does not interact with others well then his performance will not be able to develop.

When we interact with people who come from a culture different from ours, our task gets heavier. It is due to differences in specific patterns of interaction between ourselves and others from different cultures. Interpersonal skills are one's ability to be sensitive to the feelings of others so that it is easy to socialize with the surrounding environment [25]. The aspects of interpersonal skills related to attitudes that will be performed by employees and is a psychological process of creating interpersonal skills for employees in the company, including Self-awareness, namely how far individuals know themselves. The ability to hear, namely how competent a person is to be a good listener. Empathy and understanding, namely how individuals understand the surrounding environment that has a different cultural background. The ability to communicate, which is related to the ability of individuals to interact with others who have different cultures [26]. 


\section{METHODOLOGY}

This research approach is quantitative. According to Rusiadi (2013: 14), the research approach used in this study is quantitative, research that aims to determine the relationship between two or more variables with this research, a theory that functions to explain, predict and control a symptom will be built.

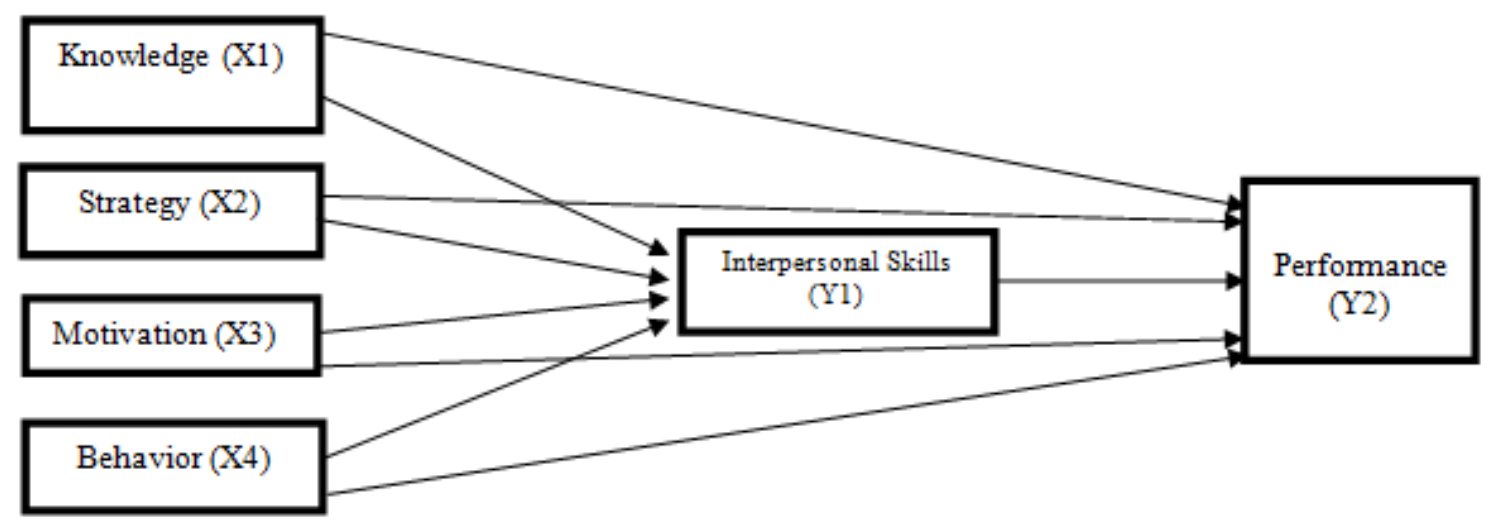

Figure 1 Thinking Framework

\subsection{Path Analysis}

The data analysis technique used in this study is the analysis of structural equation paths described by the following formula.

1. Path analysis equation (first)

$\mathrm{Y} 1=\mathrm{PY} 1 \mathrm{X} 1+\mathrm{PY} 1 \mathrm{X} 2+\mathrm{PY} 1 \mathrm{X} 3+\mathrm{PY} 1 \mathrm{X} 4+\varepsilon_{1}$

2. Path analysis equation (first)

$\mathrm{Y} 2=\mathrm{PY} 1 \mathrm{Y} 1+\dot{\varepsilon}_{1}$

3. Path analysis equation (first)

$\mathrm{Y} 2=\mathrm{PY} 1 \mathrm{X} 1+\mathrm{PY} 1 \mathrm{X} 2+\mathrm{PY} 1 \mathrm{X} 3+\mathrm{PY} 1 \mathrm{X} 4+\dot{\varepsilon}_{1}$

4. Path analysis equation (second)

$\mathrm{Y} 2=\mathrm{PY} 2 \mathrm{X} 1+\mathrm{PY} 2 \mathrm{X} 2+\mathrm{PY} 2 \mathrm{X} 3+\mathrm{PY} 2 \mathrm{X} 4+\mathrm{PY} 2 \mathrm{Y} 1+\dot{\varepsilon}_{2}$

Where:

$\mathrm{Y} \quad=$ Interpersonal skills (Endogenus Variable $)$

$\mathrm{Y} 2=$ Employee performance (Endogenus Variable)

$\mathrm{X} 1=$ Knowledge (Eksogenus Variable)

$\mathrm{X} 2=$ Strategy (Eksogenus Variable)

$\mathrm{X} 3=$ Motivation (Eksogenus Variabel)

$\mathrm{X} 4=$ Behavior (Eksogenus Variabel)

'E = Error Term / Error Rate

\section{RESULT AND DISCUSSION}

\subsection{Coeffient}

Based on the results of path analysis shows that knowledge has a direct effect on perfoThis determination analysis is used to determine the percentage of the variation in the effect of the independent variable on the dependent variable. 
Abdi Setiawan, Hasrul Azwar Hasibuan, A.P.U. Siahaan, Muhammad Isa Indrawan, Rusiadi, Irma Fatmawati, Emy Wakhyuni, Desi Astuti, Ade Novalina, Sri Rahayu

Table 1. Coefficient of Determination of Interpersonal Skills

\begin{tabular}{|c|c|c|c|c|}
\hline Model & $\mathrm{R}$ & $\mathrm{R}$ Square & Adjusted R Square & $\begin{array}{c}\text { Std. Error of the } \\
\text { Estimate }\end{array}$ \\
\hline 1 & $.568^{\mathrm{a}}$ & .323 & .311 & 3.07533 \\
\hline
\end{tabular}

a. Predictors: (Constant). knowledge

Table 2. Coefficient of Determination on performance

\begin{tabular}{|c|c|c|c|c|}
\hline Model & $\mathrm{R}$ & $\mathrm{R}$ Square & Adjusted R Square & Std. Error of the Estimate \\
\hline 1 & $.704^{\mathrm{a}}$ & .495 & .477 & 2.89068 \\
\hline
\end{tabular}

a. Predictors: (Constant), interpersonal skills, knowledge

Based on the table above can be seen the coefficient of determination of:

$$
\begin{aligned}
\mathrm{Pe}_{1} & =\sqrt{1-0.568^{2}}=0.823 \\
\mathrm{Pe}_{2} & =\sqrt{1-0.704^{2}}=0.710 \\
\mathrm{R} 2 \mathrm{~m} & =1-\mathrm{P}^{2} \mathrm{e}_{1} \cdot \mathrm{P}^{2} \mathrm{e}_{2} \\
& =1-(0.823)^{2}(0.710)^{2} \\
& =1-(0.677)(0.504) \\
& =0.65 \\
& =65.0 \%
\end{aligned}
$$

The coefficient of determination of $65.0 \%$ indicates that $65.0 \%$ of the information contained in the data can be explained by the model, while the remaining $100 \%-65 \%=$ $35.0 \%$ is explained by errors and other variables outside the model. The number of coefficients in this model is relatively large so it is worth doing further interpretation.

Table 3. Coefficient of Determination of Interpersonal Skills

\begin{tabular}{|c|c|c|c|c|}
\hline Model & $\mathrm{R}$ & $\mathrm{R}$ Square & Adjusted R Square & $\begin{array}{c}\text { Std. Error of the } \\
\text { Estimate }\end{array}$ \\
\hline 1 & $.707^{\mathrm{a}}$ & .500 & .491 & 2.64339 \\
\hline
\end{tabular}

a. Predictors: (Constant). strategies

Table 4. Coefficient of Determination of performance

\begin{tabular}{|c|c|c|c|c|}
\hline Model & $\mathrm{R}$ & R Square & Adjusted R Square & $\begin{array}{c}\text { Std. Error of the } \\
\text { Estimate }\end{array}$ \\
\hline 1 & $.651^{\mathrm{a}}$ & .423 & .403 & 3.08918 \\
\hline
\end{tabular}

a. Predictors: (Constant), interpersonal skills, strategies 
Based on the table above can be seen the coefficient of determination of:

$$
\begin{aligned}
\mathrm{Pe}_{1} & =\sqrt{1-0.707^{2}}=0.707 \\
\mathrm{Pe}_{2} & =\sqrt{1-0.651^{2}}=0.759 \\
\mathrm{R}_{2} \mathrm{~m} & =1-\mathrm{P}^{2} \mathrm{e}_{1} \cdot \mathrm{P}^{2} \mathrm{e}_{2} \\
& =1-(0.707)^{2}(0.759)^{2} \\
& =1-(0.499)(0.576) \\
& =0.71 \\
& =71.0 \%
\end{aligned}
$$

The coefficient of determination of $71.0 \%$ shows that $71.0 \%$ of the information contained in the data can be explained by the model, while the remaining $100 \%-71.0 \%=29 \%$ is explained by errors and other variables outside the model. The number of coefficients in this model is relatively large, so it is worth making the further interpretation.

Table 5. Coefficient of Determination of Interpersonal Skills

\begin{tabular}{|c|c|c|c|c|}
\hline Model & $\mathrm{R}$ & $\mathrm{R}$ Square & Adjusted R Square & Std. Error of the Estimate \\
\hline 1 & $.618^{\mathrm{a}}$ & .382 & .371 & 2.93913 \\
\hline
\end{tabular}

a. Predictors: (Constant). motivation

Table 6. Coefficient of Determination of performance

\begin{tabular}{|c|c|c|c|c|}
\hline Model & $\mathrm{R}$ & R Square & Adjusted R Square & $\begin{array}{c}\text { Std. Error of the } \\
\text { Estimate }\end{array}$ \\
\hline 1 & $.787^{\mathrm{a}}$ & .619 & .606 & 2.50969 \\
\hline
\end{tabular}

a. Predictors: (Constant), interpersonal skills, motivation

Based on Table 4. can be seen the coefficient of determination of:

$$
\begin{aligned}
\mathrm{Pe}_{1} & =\sqrt{1-0,618^{2}}=0.786 \\
\mathrm{Pe}_{2} & =\sqrt{1-0.787^{2}}=0.616 \\
\mathrm{R} 2 \mathrm{~m} & =1-\mathrm{P}^{2} \mathrm{e}_{1} \cdot \mathrm{P}^{2} \mathrm{e}_{2} \\
& =1-(0.786)^{2}(0.616)^{2} \\
& =1-(0.617)(0.379) \\
& =0.76 \\
& =76.0 \%
\end{aligned}
$$

The coefficient of determination of $76.0 \%$ indicates that $76.0 \%$ of the information contained in the data can be explained by the model, while the remaining $100 \%-76 \%=$ $24.0 \%$ is explained by errors and other variables outside the model. The number of coefficients in this model is relatively large, so it is worth making the further interpretation. 
Abdi Setiawan, Hasrul Azwar Hasibuan, A.P.U. Siahaan, Muhammad Isa Indrawan, Rusiadi, Irma Fatmawati, Emy Wakhyuni, Desi Astuti, Ade Novalina, Sri Rahayu

Table 7. Coefficient of Determination of Interpersonal Skills

\begin{tabular}{|c|c|c|c|c|}
\hline Model & $\mathrm{R}$ & R Square & Adjusted R Square & $\begin{array}{c}\text { Std. Error of the } \\
\text { Estimate }\end{array}$ \\
\hline 1 & $.716^{\mathrm{a}}$ & .513 & .505 & 2.60824 \\
\hline
\end{tabular}

a. Predictors: (Constant). behavior

Table 8. Coefficient of Determination of performance

\begin{tabular}{|c|c|c|c|c|}
\hline Model & $\mathrm{R}$ & R Square & Adjusted R Square & $\begin{array}{c}\text { Std. Error of the } \\
\text { Estimate }\end{array}$ \\
\hline 1 & $.599^{\mathrm{a}}$ & .358 & .336 & 3.25845 \\
\hline
\end{tabular}

a. Predictors: (Constant). interpersonal skills. behavior

Based on the table can be seen the coefficient of determination of:

$$
\begin{aligned}
\mathrm{Pe}_{1} & =\sqrt{1-0.716^{2}}=0.698 \\
\mathrm{Pe}_{2} & =\sqrt{1-0.599^{2}}=0.800 \\
\mathrm{R} 2 \mathrm{~m} & =1-\mathrm{P}^{2} \mathrm{e}_{1} \cdot \mathrm{P}^{2} \mathrm{e}_{2} \\
& =1-(0.698)^{2}(0.800)^{2} \\
& =1-(0.487)(0.64) \\
& =0.68 \\
& =68.0 \%
\end{aligned}
$$

The coefficient of determination of $68.0 \%$ indicates that $68.0 \%$ of the information contained in the data can be explained by the model, while the remaining $100 \%-68.0 \%=$ $32 \%$ is explained by errors and other variables outside the model. The number of coefficients in this model is relatively large, so it is worth making the further interpretation.

Table 9. Coefficients ${ }^{\mathrm{a}}$

\begin{tabular}{|cc|c|c|c|c|c|}
\hline \multirow{2}{*}{} & \multicolumn{2}{|c|}{} & \multicolumn{2}{|c|}{$\begin{array}{c}\text { Standardized } \\
\text { Coefficients }\end{array}$} & \multirow{2}{*}{} \\
\cline { 2 - 5 } & Model & $\mathrm{B}$ & Std. Error & Beta & $\mathrm{t}$ & Sig. \\
\hline \multirow{2}{*}{1} & (Constant) & 15.492 & 5.128 & & 3.021 & .004 \\
& pengetahuan & .604 & .115 & .568 & 5.260 & .000 \\
\hline
\end{tabular}

Dependent Variable: interpersonal skills

Table 10. Model Summary

\begin{tabular}{|c|c|c|c|c|}
\hline Model & $\mathrm{R}$ & R Square & Adjusted R Square & Std. Error of the Estimate \\
\hline 1 & $.568^{\mathrm{a}}$ & .323 & .311 & 3.07533 \\
\hline
\end{tabular}

a. Predictors: (Constant), knowledge 
Based on table 4.119 and table 4.120 above, the standardized beta value for knowledge is 0.568 and is significant at 0.000 , which means knowledge influences interpersonal skills. The value of the standardized beta 0.568 is the path value or path $\mathrm{P} 1$. The value of $\mathrm{e} 1=(1-0.311)$ $2=0.474$. Equation $\mathrm{I}=\mathrm{Y} 1=0.568 \mathrm{X} 1+0.474 € 1$.

Table 11. Coefficients ${ }^{\mathrm{a}}$

\begin{tabular}{|c|c|c|c|c|c|c|}
\hline \multirow{2}{*}{\multicolumn{2}{|c|}{ Model }} & \multicolumn{2}{|c|}{ Unstandardized Coefficient } & $\begin{array}{l}\text { Standardized } \\
\text { Coefficients }\end{array}$ & \multirow[b]{2}{*}{ t } & \multirow[b]{2}{*}{ Sig. } \\
\hline & & $\mathrm{B}$ & Std. Error & Beta & & \\
\hline \multirow[t]{2}{*}{1} & (Constant) & 14.158 & 3.724 & & 3,802 & 000 \\
\hline & strategi & .646 & .085 & .707 & 7,612 & 000 \\
\hline
\end{tabular}

a. Dependent Variable: interpersonal skills

Table 12. Model Summary

\begin{tabular}{|c|c|c|c|c|}
\hline Model & $\mathrm{R}$ & $\mathrm{R}$ Square & $\begin{array}{c}\text { Adjusted } \mathrm{R} \\
\text { Square }\end{array}$ & Std. Error of the Estimate \\
\hline 1 & $.707^{\mathrm{a}}$ & .500 & .491 & 2.64339 \\
\hline
\end{tabular}

a. Predictors: (Constant), strategies

Based on the table the standardized beta value for the strategy is 0.707 and is significant at 0.000 , which means that the strategy influences interpersonal skills. The standardized beta value of 0.707 is the path value or path $\mathrm{P} 1$. The value of $\mathrm{e} 1=(1-0,491) 2=0,259$. Equation $\mathrm{I}$ $=\mathrm{Y} 1=0.707 \mathrm{X} 2+0.259 € 1$.

Table 12. Coefficients ${ }^{\mathrm{a}}$

\begin{tabular}{|c|c|c|c|c|c|c|}
\hline \multirow{2}{*}{\multicolumn{2}{|c|}{ Model }} & \multicolumn{2}{|c|}{ Unstandardized Coefficients } & $\begin{array}{c}\text { Standardized } \\
\text { Coefficients }\end{array}$ & \multirow[b]{2}{*}{$\mathrm{t}$} & \multirow[b]{2}{*}{ Sig. } \\
\hline & & B & Std. Error & Beta & & \\
\hline & (Constant) & 14.949 & 4.602 & & 3.249 & .002 \\
\hline & motivasi & .651 & .109 & .618 & 5.982 & .000 \\
\hline
\end{tabular}

a. Dependent Variable: interpersonal skills

Table 13. Model Summary

\begin{tabular}{|c|c|c|c|c|}
\hline Model & $\mathrm{R}$ & $\mathrm{R}$ Square & $\begin{array}{c}\text { Adjusted } \mathrm{R} \\
\text { Square }\end{array}$ & Std. Error of the Estimate \\
\hline 1 & $.618^{\mathrm{a}}$ & .382 & .371 & 2.93913 \\
\hline
\end{tabular}

a. Predictors: (Constant), motivation

Based on the table above, the standardized beta value for motivation is 0.618 and is significant at 0.000 which means that motivation affects interpersonal skills. The standardized beta coefficient value 0.618 is the path value or path P1. The value of $\mathrm{e} 1=(1-0,371) 2=$ 0,395 . Equation $\mathrm{I}=\mathrm{Y} 1=0.618 \mathrm{X} 3+0.395 € 1$.

Based on the table above, the standardized beta value for behavior is 0.716 and is significant at 0.000 , which means that behavior affects interpersonal skills. The standardized beta coefficient value 0.716 is the path value or path $\mathrm{P} 1$. The value of e1 $=(1-0.505) 2=$ 0.245. Equation I: Y1 $=0.716 \mathrm{X} 4+0.245 € 1$. 
Abdi Setiawan, Hasrul Azwar Hasibuan, A.P.U. Siahaan, Muhammad Isa Indrawan, Rusiadi, Irma Fatmawati, Emy Wakhyuni, Desi Astuti, Ade Novalina, Sri Rahayu

Based on the table the standardized beta value for knowledge is 0.536 and is significant at 0.000 which means that knowledge affects performance. The standardized beta value of 0.536 is the path value or P3 path. The standardized beta value for interpersonal skills is 0.244 and is significant at 0.037 , which means that interpersonal skills affect performance. Standardized coefficient value 0.244 beta is the path value or path P2. The value of e2 $=(1-0.477) 2=$ 0.273. Equation II: Y2 $=0.536 \mathrm{X} 1+0.244 \mathrm{Y} 1+0.273 € 2$.

\subsection{Mediation Test}

Based on the results of path analysis shows that knowledge has a direct effect on performance and can also have an indirect effect, from the influence of knowledge to interpersonal skills (as an intervening variable) and then to performance. The amount of direct influence is 0.536 , while the amount of indirect effect must be calculated by multiplying the indirect coefficient of $0.568 \times 0.244=0.138$ or the total effect of knowledge to performance $=0.536+(0.568 \times$ $0.244)=0.674$. Because of the value $(\mathrm{P} 1 \times \mathrm{P} 2<\mathrm{P} 3)$ then interpersonal skills do not function as an intervening variable.

Based on the results of path analysis shows that the strategy has a direct effect on performance and can also have an indirect effect, from the influence of strategy to interpersonal skills (as an intervening variable) and then to performance. The amount of direct influence is 0.495 , while the magnitude of the indirect effect must be calculated by multiplying the indirect coefficient of $0.707 \times 0.244=0.172$ or the total effect of the strategy to performance $=0.495+(0.707 \times 0.244)=0.667$. Because of the value $(\mathrm{P} 1 \times \mathrm{P} 2<\mathrm{P} 3)$ then interpersonal skills do not function as an intervening variable.

Based on the results of path analysis shows that motivation directly affects performance and can also have an indirect effect, from the influence of motivation to interpersonal skills (as an intervening variable) and then to performance. The amount of direct influence is 0.718 , while the amount of indirect influence must be calculated by multiplying the indirect coefficient, which is $0.618 \times 0.105=0.064$ or the total effect of motivation to performance $=$ $0.718+(0.618 \times 0.105)=0.782$. Because of the value $(\mathrm{P} 1 \times \mathrm{P} 2<\mathrm{P} 3)$ then interpersonal skills do not function as an intervening variable. Based on the results of path analysis shows that behavior directly affects performance and can also have an indirect effect, from the influence of knowledge to interpersonal skills (as an intervening variable) and then to performance. The amount of direct influence is 0.345 , while the amount of indirect effect must be calculated by multiplying the indirect coefficient, which is $0.716 \times 0.301=0.215$ or the total effect of behavior to performance $=0.345+(0.716 \times 0.301)=0.56$. Because of the value $(\mathrm{P} 1 \times \mathrm{P} 2$ $<\mathrm{P} 3)$ then interpersonal skills do not function as an intervening variable.

\section{CONCLUSIONS}

Based on the results of data analysis it is known that knowledge has a direct effect on performance and can also have an indirect effect, from knowledge to interpersonal skills to performance. Based on the results of data analysis it is known that the strategy directly affects performance and can also have an indirect effect, from strategy to interpersonal skills to performance. Based on the results of data analysis it is known that motivation directly affects performance and can also have an indirect effect, from motivation to interpersonal skills than to performance. Based on the results of data analysis it is known that behavior directly affects performance and can also have an indirect effect, from behavior to interpersonal skills to performance. 
Dimensions of Cultural Intelligence and Technology Skills on Employee Performance

\section{REFERENCES}

[1] P. A. Mangkunegara, Evaluasi Kinerja SDM. Bandung: Rafika Aditama, 2010.

[2] Rusiadi dan A. Novalina, "Monetary Policy Transmission: Does Maintain the Price and Poverty Stability is Effective?," Jejak J. Ekon. dan Kebijak., vol. 11, no. 102, hal. 78-82, 2018.

[3] Rusiadi, Ramli, D. Ruslan, dan R. Ginting, "Monetary Transmission Of State Emerging Markets Line Asset Prices: Inflation Control Leading Indicators," Int. J. Civ. Eng. Technol., vol. 9, no. 7, hal. 698-707, 2018.

[4] A. J., "Determinants of employee engagement and their impact on employee performance," Int. J. Product. Perform. Manag., vol. 63, no. 3, hal. 308-323, Apr 2014.

[5] I. Ahmed, I. Sultana, S. K. Paul, dan A. Azeem, "Employee performance evaluation: a fuzzy approach," Int. J. Product. Perform. Manag., vol. 62, no. 7, hal. 718-734, Sep 2013.

[6] A. H. Lubis, S. Z. S. Idrus, dan A. Sarji, "ICT Usage Amongst Lecturers and Its Impact Towards Learning Process Quality," vol. 34, no. 1, hal. 284-299, 2018.

[7] A. I. F. Lubis et al., "Strategy for Improving Science and Welfare Through Community Empowerment Technology," Int. J. Civ. Eng. Technol., vol. 9, no. 9, hal. 1036-1046, 2018.

[8] R. B. Sappey dan J. Sappey, "Different skills and knowledge for different times: training in an Australian retail bank," Empl. Relations, vol. 21, no. 6, hal. 577-589, Des 1999.

[9] A. Ikhwan, M. Yetri, Y. Syahra, dan J. Halim, "A Novelty of Data Mining for Promoting Education based on FP-Growth Algorithm," Int. J. Civ. Eng. Technol., vol. 9, no. 7, hal. $1660-1669,2018$.

[10] Y. Rossanty, S. Aryza, M. D. T. P. Nasution, dan A. P. U. Siahaan, "Design Service of QFC And SPC Methods in the Process Performance Potential Gain and Customers Value in a Company," Int. J. Civ. Eng. Technol., vol. 9, no. 6, hal. 820-829, 2018.

[11] M. D. T. P. Nasution, Y. Rossanty, P. B. Sari, dan A. P. U. Siahaan, "Online Shoppers Acceptance: an Exploratory Study,” Int. J. Civ. Eng. Technol., vol. 9, no. 6, hal. 793-799, 2018.

[12] L. Lu, "Working hours and personal preference among Taiwanese employees," Int. J. Work. Heal. Manag., vol. 4, no. 3, hal. 244-256, Sep 2011.

[13] D. Buchanan dan A. Huczynski, "B-CAP: A New Approach to Interpersonal Skills Development," J. Eur. Ind. Train., vol. 10, no. 8, hal. 27-30, Agu 1986.

[14] P. L. Wright dan D. S. Taylor, "Developing Tutoring Skills for Interpersonal Skills Trainers," J. Eur. Ind. Train., vol. 8, no. 6, hal. 27-32, Jun 1984.

[15] K. C. Huff, "Language, cultural intelligence and expatriate success," Manag. Res. Rev., vol. 36, no. 6, hal. 596-612, Mei 2013.

[16] C. E. Earley, "Knowledge Acquisition in Auditing: Training Novice Auditors to Recognize Cue Relationships in Real Estate Valuation," Account. Rev., vol. 76, no. 1, hal. 81-97, Jan 2001.

[17] P. Piperopoulos, "Could higher education programmes, culture and structure stifle the entrepreneurial intentions of students?," J. Small Bus. Enterp. Dev., vol. 19, no. 3, hal. 461-483, Agu 2012.

[18] K. A. Crowne, "What leads to cultural intelligence?," Bus. Horiz., vol. 51, no. 5, hal. 391399, Sep 2008. 
Abdi Setiawan, Hasrul Azwar Hasibuan, A.P.U. Siahaan, Muhammad Isa Indrawan, Rusiadi, Irma Fatmawati, Emy Wakhyuni, Desi Astuti, Ade Novalina, Sri Rahayu

[19] S. Ang, L. Van Dyne, dan M. L. Tan, "Cultural Intelligence," in The Cambridge Handbook of Intelligence, R. J. Sternberg dan S. B. Kaufman, Ed. Cambridge: Cambridge University Press, 2011, hal. 582-602.

[20] S. E. Asch, Social psychology. Englewood Cliffs: Prentice-Hall, Inc, 1952.

[21] G. Hofstede, "Dimensionalizing Cultures: The Hofstede Model in Context," Online Readings Psychol. Cult., vol. 2, no. 1, Des 2011.

[22] H. A. Hasibuan, R. B. Purba, dan A. P. U. Siahaan, "Productivity Assessment (Performance, Motivation, and Job Training) using Profile Matching," Int. J. Econ. Manag. Stud., vol. 3, no. 6, hal. 73-77, 2016.

[23] A. K. Sari, H. Saputra, dan A. P. U. P. U. Siahaan, "Financial Distress Analysis on Indonesia Stock Exchange Companies," Int. J. Innov. Res. Multidiscip. F., vol. 4, no. 3, hal. 73-74, 2018.

[24] S. Suroso et al., "Autoregression Vector Prediction on Banking Stock Return using CAPM Model Approach and Multi-Factor APT," Int. J. Civ. Eng. Technol., vol. 9, no. 9, hal. 1093-1103, 2018.

[25] N. Mead dan P. Bower, "Patient-centredness: a conceptual framework and review of the empirical literature," Soc. Sci. Med., vol. 51, no. 7, hal. 1087-1110, Okt 2000.

[26] S. Marks, "Health, Development, and Human Rights," in Health and Development, London: Palgrave Macmillan UK, 2009, hal. 124-139. 